\title{
Corrosion inhibition of carbon steel in various water types by zinc gluconate
}

\section{Korrosionsinhibierung von Kohlenstoffstahl durch Zinkgluconat in verschiedenen Wasserarten}

\author{
F. Ivušić ${ }^{1}$, O. Lahodny-Šarc ${ }^{1}$, V. Alar
}

The effect of zinc gluconate on the corrosion inhibition of carbon steel DIN RSt 37-2 in various water types has been evaluated using Tafel polarization and scanning electron microscopy techniques. Experiments were performed using 6 types of water, namely, soft tap water from Dubrovnik region, hard tap water from Zagreb region, 3.5\% sodium chloride solution, sea water from Dubrovnik region, biologically inert sea water from Dubrovnik region and demineralized water. The concentration of zinc gluconate varied from 0.1 to $3 \mathrm{gl}^{-1}$. The results show that substantial corrosion inhibition using zinc gluconate can be obtained with low concentrations in tap waters along with demineralized water and with moderate concentrations in $3.5 \%$ sodium chloride solution and sea waters. EDX analysis confirmed the presence of zinc ions which are incorporated in the protective layer of carbon steel specimen. The corrosion inhibition is predominately obtained by anodic mechanism.

Keywords: carbon steel / corrosion inhibition / zinc gluconate / sea water / tap water

Die Wirkung von Zinkgluconat auf die Korrosionsinhibierung des Kohlenstoffstahls DIN RSt 37-2 in verschiedenen Wasserarten anhand der Tafel Polarisation und der Rasterelektronenmikroskopie wurde untersucht. Die Experimente wurden unter Verwendung von 6 Arten von Wasser durchgeführt, nämlich: weiches Leitungswasser der Dubrovnik Region, hartes Leitungswasser der Zagreb Region, eine 3,5\% Natriumchloridlösung, Meerwasser der Dubrovnik Region, biologisch inertes Meerwasser der Dubrovnik Region und demineralisiertes Wasser. Die Konzentration von Zinkgluconat variierte von $0,1-3$ bis $\mathrm{gl}^{-1}$. Die Ergebnisse zeigten, dass schon bei niedrigen Konzentrationen von Zinkgluconat in Leitungswasser und demineralisiertem Wasser eine erhebliche Korrosionsinhibierung erreicht werden kann, während für die Inhibierung im Meereswasser, inerten Wasser und in einer 3,5\% Natriumchloridlösung, eine etwas höhere Konzentration des Zinkgluconat erforderlich ist. Die EDX-Analyse bestätigte die Anwesenheit von Zink lonen, die vermutlich in der Schutzschicht des Kohlenstoffstahles inkorporiert sind. Die Korrosionsinhibierung wird überwiegend durch einen anodischen Mechanismus hervorgerufen.

Schlüsselwörter: Kohlenstoffstahl / Korrosioninhibition / Zinkgluconat / Meerwasser / Leitungswasser

\section{Introduction}

Gluconic acid and its salts (sodium, calcium and zinc gluconate) are known to be convenient corrosion inhibitors for carbon steel in many applications, particularly as scaling and corrosion inhibitors in cooling water systems [1-6]. They are environmentally

\footnotetext{
${ }^{1}$ The Institute for Corrosion Research and Desalinization, Croatian Academy of Sciences and Arts, Dubrovnik, Croatia

${ }^{2}$ Faculty of Mechanical Engineering and Naval Architecture, University of Zagreb, Zagreb, Croatia

Correspondence author: F. Ivušić, The Institute for Corrosion Research and Desalinization, Croatian Academy of Sciences and Arts, Vlaha Bukovca 14, 20000 Dubrovnik, Croatia

E-mail: fivusic@hazu.hr
}

suitable non-toxic compounds having also useful applications in medicine. For example, calcium gluconate is used as a health strengthening substance as well as for the treatment of calcium deficiency. Zinc gluconate is used for common cold treatment and for better wound healing. A number of recent studies have been carried out on the efficiency and the mechanism of the gluconate corrosion inhibition either as single compound or in a mixture [2, 3, 7-15]. The efficiency of gluconate inhibition depends on inhibitor concentration, $\mathrm{pH}$ value and chemical composition of investigated solution, the nature of cations introduced in the solution as gluconate or already present in water and the state of the metal surface $[11,16]$. Gluconates are part of the successful commercial corrosion inhibitors and are recommended in mixture with water soluble polymeric dispersant, organophosphonate and silicate [17]. In previous researches the anodic inhibition mechanism of mild steel corrosion using sodium gluconate 
has been shown $[18,19]$. The influence of bivalent ions $\left(\mathrm{Ca}^{2+}\right.$ and $\mathrm{Zn}^{2+}$ ) on the decrease of the cathodic reaction rate was recognized in solutions of their gluconate salts. This inhibition of the cathodic reaction can be attributed to the formation of calcium and zinc hydroxides or a sparingly soluble metal gluconate complex formed on the cathodic areas in the presence of air. After anodic polarization of iron sample in sodium boron gluconate solution, boron gluconate has been detected by Auger analysis incorporated in protective oxide layer of the iron sample and not directly on the metal surface [19]. Several mechanisms of corrosion inhibition by gluconate were proposed. It is speculated that gluconate can repair the oxide film by adsorption on the exposed metal surface in weak spots of porous oxide film. Gluconates can be incorporated in the oxide film during its formation and/or gluconate are forming more or less soluble complexes that can be precipitated on the metal surface [11]. A successful inhibition of mild steel and zinc was obtained in the seawater and solutions containing different chloride concentrations by zinc gluconate $[18,20,21]$. Since the seawater and different brines are increasingly used in industrial practice (cooling water systems, desalination plants, injection water) due to the both economical and ecological grounds, these results are of considerable practical application. Gluconates are suitable for applications in hard waters due to their sequestering properties. The mixture of sodium gluconate with boric acid has been shown to prevent the precipitation of multivalent ions, such as $\mathrm{Ca}^{2+}, \mathrm{Mn}^{2+}$ and $\mathrm{Cu}^{2+}$ from hard waters by complexing [16]. The aim of this research was to systematically evaluate and compare the effect of zinc gluconate concentration on corrosion inhibition of carbon steel in various water types and to estimate optimal concentrations of zinc gluconate required for satisfactory inhibition.

\section{Experimental}

All experiments were performed using carbon steel specimen DIN RSt $37-2$ of following composition: C $0.17 \%$, P $0.05 \%, \mathrm{~S}$ $0.05 \%, \mathrm{~N} 0.007 \%$ (working electrode with a $1 \mathrm{~cm}^{2}$ area). Before measurements the specimen was polished with emery paper (400, 600, 800 and 1200 grade) degreased with ethanol and rinsed with demineralized water. Afterwards the working electrode was immersed in electrochemical cell containing $600 \mathrm{ml}$ of investigated medium. All experiments were performed at ambient temperature $\left(22 \pm 2^{\circ} \mathrm{C}\right)$. $\mathrm{pH}$ values of investigated media were measured using $\mathrm{pH}$ meter Mettler Toledo, SevenMulti. The electrochemical cell was equipped with graphite auxiliary electrode and a reference saturated calomel electrode which was connected to the working electrode over Luggin capillary. Electrocemical measurements were performed on Potentiostat/Galvanostat EG\&G PAR, Model 273 A using software SoftCorr III. The open circuit potential (OCP) was measured as a function of time in order to understand the corrosion behavior of the sample in the electrolyte. A soon as the sample was immersed into the electrolyte, the initial potential of the sample was noted and monitored as a function of time until the sample attained a constant potential $E_{\text {corr }}$ (typically 30-60 $\mathrm{min}$ ). Afterwards, linear polarization method was applied (from $-20 \mathrm{mV}$ to $+20 \mathrm{mV}$, polarization rate $0.166 \mathrm{mVs}^{-1}$ ) in order to calculate the value of polarization resist-
Table 1. The chemical composition of different water types

Tabelle 1. Chemische Zusammensetzung verschiedener Wasserarten

\begin{tabular}{lllll}
\hline $\begin{array}{l}\text { Parameter } \\
\left(\mathrm{mgl}^{-1}\right)\end{array}$ & STW & HTW & $\begin{array}{l}3.5 \% \\
\mathrm{NaCl}\end{array}$ & SW \\
\hline Ca hardness & 189 & 377 & 216 & 4523 \\
Total hardness & 216 & 419 & 330 & 10135 \\
$\mathrm{KMnO}_{4}$ & 0.6 & 1.6 & - & 14.8 \\
$\mathrm{Ca}$ & 75.6 & 150.8 & 86.4 & 1809.2 \\
$\mathrm{Mg}$ & 6.56 & 10.2 & 27.7 & 1364 \\
$\mathrm{Fe}$ & 0.02 & 0.02 & 0.66 & 0.48 \\
$\mathrm{Cl}$ & 14.6 & 25.1 & 22150 & 21777 \\
$\mathrm{Zn}$ & 0.01 & $<0.01$ & 0.08 & 0.03 \\
$\mathrm{Ni}$ & $<0.001$ & $<0.001$ & 0.78 & 0.68 \\
$\mathrm{Cu}$ & $<0.01$ & $<0.01$ & 0.12 & 0.08 \\
$\mathrm{Cr}$ & $<0.01$ & $<0.01$ & 0.16 & 0.26 \\
$\mathrm{Cd}$ & $<0.005$ & $<0.005$ & 0.1 & 0.09 \\
$\mathrm{~Pb}^{-}$ & 0.01 & $<0.01$ & 0.29 & 0.38 \\
$\mathrm{NH}_{4}{ }^{+}$ & $<0.005$ & $<0.005$ & $<0.005$ & $<0.005$ \\
$\mathrm{NO}_{2}{ }^{-}$ & $<0.005$ & $<0.005$ & $<0.005$ & $<0.005$ \\
$\mathrm{NO}_{3}{ }^{-}$ & 2.4 & 10.1 & 2.3 & 2.2 \\
\hline
\end{tabular}

ance $\left(R_{\mathrm{P}}\right)$. Finally, the method of quasi potentiostatic polarization or the Tafel extrapolation method was carried out recording polarization curves in the range \pm 250 from the corrosion potential $\left(E_{\text {corr }}\right)$ with a polarization rate $0.1666 \mathrm{mVs}^{-1}$. From Tafel polarization curves following corrosion parameters were calculated: the corrosion current density $\left(j_{\text {corr }}\right)$ and corrosion rate $\left(v_{\text {corr }}\right)$. The inhibition efficiency $(Z)$ was calculated using equation (1).

Experiments were performed on 6 different water types: soft tap water from Dubrovnik region (STW), hard tap water from Zagreb region (HTW), 3.5\% $\mathrm{NaCl}$ solution (demineralized water with addition of $\mathrm{NaCl}$ ) and sea water from Dubrovnik region (SW). Five different zinc gluconate $(\mathrm{ZG})$ concentrations $(0.1,0.5$, 1,2 and $3 \mathrm{gl}^{-1}$ ) were investigated on each water type and compared to unprotected steel. The compositions of described water types are presented in Tab. 1. Additionally, experiments with optimized ZG concentrations were performed on demineralized water (DW) and biologically inert sea water from Dubrovnik region (ISW). ISW was prepared by boiling sea water for 10 minutes. Afterwards, ISW was cooled down to a working temperature. Zinc gluconate salt was used as corrosion inhibitor for electrolyte (media) preparation (p.a. Alfa Aesar). For weighting a Kern ABS 220-4 balance was used. After electrochemical measurements, the surface of the steel specimen was observed and photographed using stereomicroscope Leica MZ6 (low amplification).

Topography and elemental composition of the steel specimen was determined using scanning electron microscope VEGA TESCAN TS 5136 MM equipped with EDX analyzer (Oxford Instruments INCA energy dispersive spectroscopy) after experiment without the inhibitor addition in SW and after experiment with $1 \mathrm{gl}^{-1} \mathrm{ZG}$ addition.

$Z=\frac{j_{n i}-j_{i n h}}{j_{n i}} \times 100 ; \%$

$Z$-inhibition efficiency (\%)

$j_{n i}$ - corrosion current density of uninhibited experiment $\left(\mu \mathrm{Acm}^{-2}\right)$

$j_{\text {inh }}$ - corrosion current density of inhibited experiment $\left(\mu \mathrm{Acm}^{-2}\right)$ 


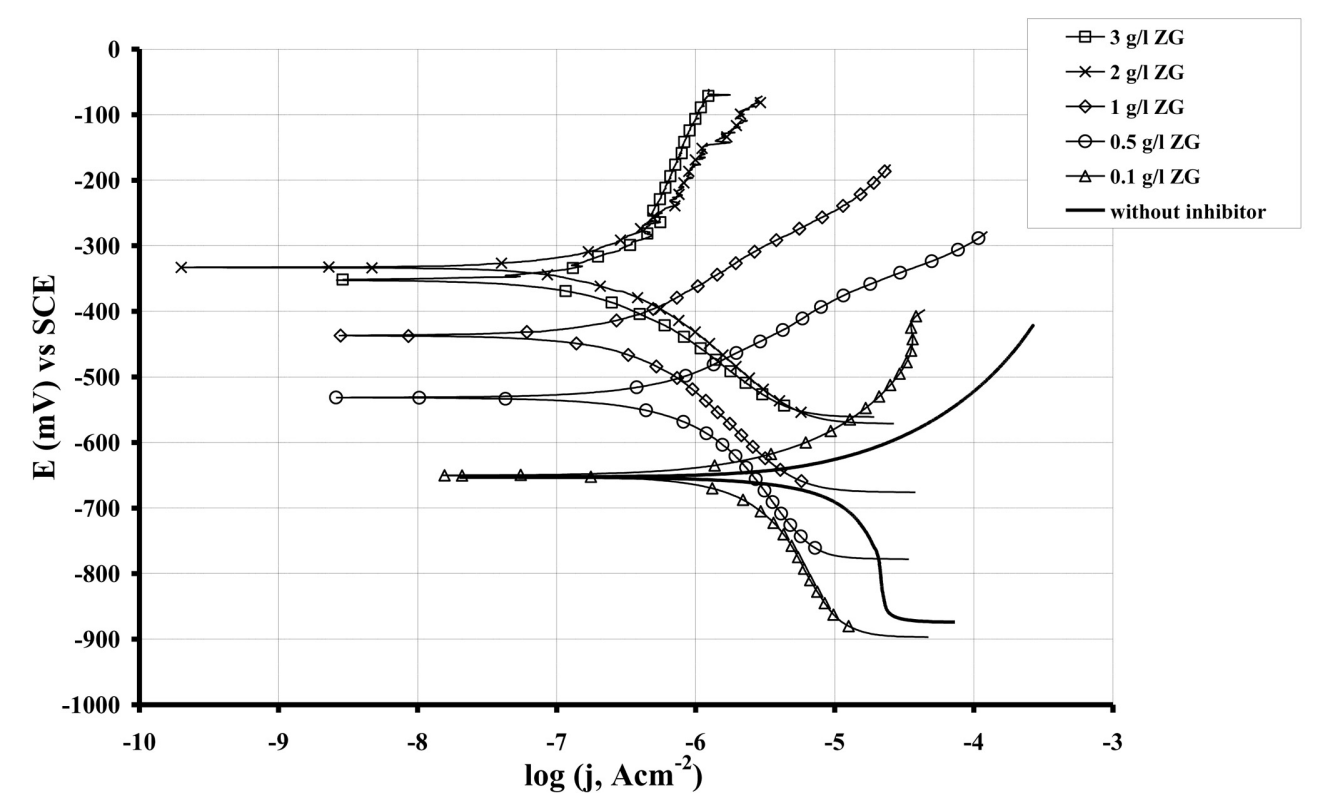

Figure 1. Tafel polarization curves of carbon steel in STW

Bild 1. Tafel Polarisationskurven von Kohlenstoffstahl in STW

Table 2. Corrosion parameters of carbon steel in soft tap water (STW)

Tabelle 2. Korrosionsparameter des Kohlenstoffstahls in weichem Leitungswasser (STW)

\begin{tabular}{|c|c|c|c|c|c|c|c|}
\hline Inhibitor & $\begin{array}{l}\text { Conc. } \\
\mathrm{gl}^{-1}\end{array}$ & $\begin{array}{l}E_{\text {corr }} \\
\mathrm{mV}\end{array}$ & $\begin{array}{l}\mathbf{v}_{\text {corr }} \\
\mathbf{m m y}^{-1}\end{array}$ & $\begin{array}{l}\mathbf{j}_{\text {corr }} \\
\mu \mathbf{A c m}^{-2}\end{array}$ & $\begin{array}{l}\mathbf{R}_{\mathbf{P}} \\
\text { kOhms }\end{array}$ & $\mathrm{pH}$ & $\begin{array}{l}Z \text { (efficiency) } \\
\%\end{array}$ \\
\hline - & 0 & -670 & 0.2603 & 22.25 & 2.635 & 8.2 & 0 \\
\hline Zn-gluconate & 0.1 & -640 & 0.0332 & 2.838 & 7.248 & 7.74 & 87.25 \\
\hline Zn-gluconate & 0.5 & -514 & 0.00798 & 0.682 & 16.68 & 7.69 & 96.93 \\
\hline Zn-gluconate & 1 & -425 & 0.0042 & 0.3589 & 28.95 & 7.43 & 98.39 \\
\hline Zn-gluconate & 2 & -325 & 0.004198 & 0.3588 & 62.75 & 7.18 & 98.39 \\
\hline Zn-gluconate & 3 & -307 & 0.004989 & 0.4264 & 88.39 & 7.22 & 98.08 \\
\hline
\end{tabular}

\section{Results and discussion}

\subsection{The effect of ZG on corrosion inhibition in soft tap water (STW)}

The effect of ZG concentration on protective properties of carbon steel in soft water was evaluated using 5 different ZG concentrations $\left(0.1,0.5,1,2\right.$ and $\left.3 \mathrm{gl}^{-1}\right)$. In order to evaluate inhibitor performance an experiment without ZG addition was also performed. Tafel polarization curves for the above mentioned concentrations are presented in Figure 1 and compared to unprotected steel. The values of corrosion parameters evaluated from electrochemical studies $\left(E_{\text {corr }}, v_{\text {corr }} j_{\text {corr }}, R_{\mathrm{P}}, Z\right)$ as well as $\mathrm{pH}$ values of investigated media are given in Tab. 2. All employed ZG concentrations have tendency to shift $E_{\text {corr }}$ value in the positive direction when compared to uninhibited curve. Likewise, all employed ZG concentrations significantly reduce the corrosion rate of carbon steel in STW. Also, $R_{\mathrm{P}}$ value increases with the increase of applied ZG concentration. Relatively high $\mathrm{pH}$ value and reduced protective cation content make this water type very corrosive $\left(0.26 \mathrm{mmy}^{-1}\right)$, Figure 2, Tab. 1. However, even the lowest applied inhibitor concentration $\left(0.1 \mathrm{gl}^{-1} \mathrm{ZG}\right)$ decreases $\mathrm{pH}$ value towards the neutral region and significantly reduces corrosion rate (efficiency at given concentration is $87.25 \%$ ). The increase of applied inhibitor concentration $\left(0.5 \mathrm{gl}^{-1} \mathrm{ZG}\right)$ further reduces corrosion rate $(96.93 \%)$. The maximal efficiency is achieved at $1 \mathrm{gl}^{-1} \mathrm{ZG}$ $\left(98.39 \%, 0.0042 \mathrm{mmy}^{-1}\right)$ and further increase of the inhibitor concentration has no significant effect on the corrosion rate. Surfaces of the carbon steel specimens after electrochemical research in STW with $\left(1 \mathrm{gl}^{-1} \mathrm{ZG}\right)$ and without inhibitor addition are presented in Figure 2. Substantial layer of corrosion products can be seen on steel carbon specimen from the uninhibited medium, whereas the protected specimen had a clean surface without visible signs of corrosion products. Considering the fact that Tafel curves have a tendency to move towards the positive potential values with the increase of inhibitor concentration, it can be concluded that ZG acts predominately as an anodic inhibitor in this water type, Figure 1. However, the lowest applied concentration hasn't showed this tendency. ZG is in fact mixed type inhibitor and this is particularly expressed at lowest applied concentration. 


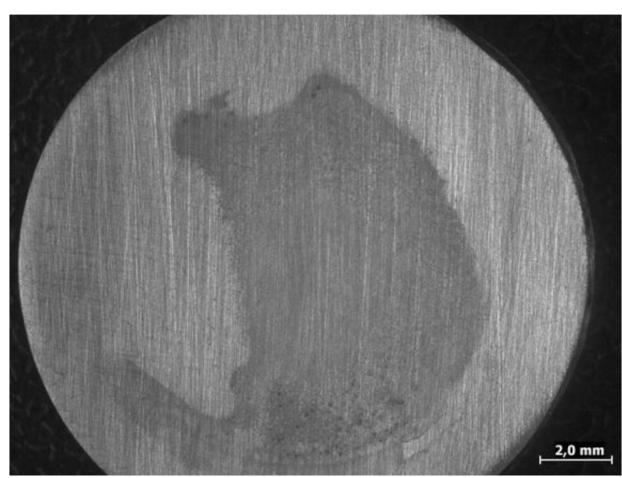

Without inhibitor

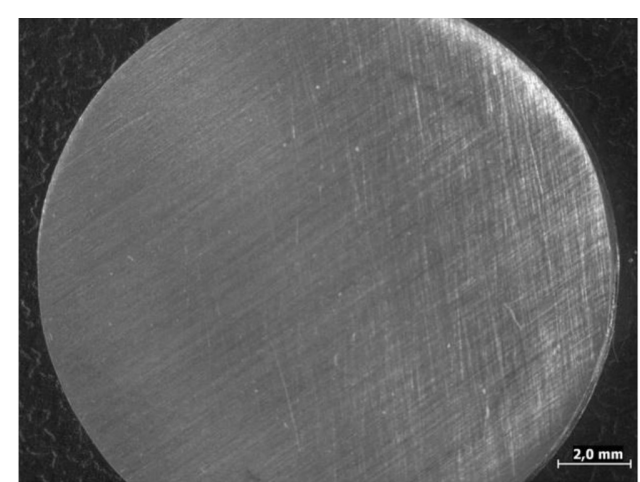

$1 \mathrm{gl}^{-1} \mathrm{ZG}$

Figure 2. Surface of the carbon steel specimens after electrochemical measurements in STW

Bild 2. Oberfläche der Kohlenstoffstahlproben nach der elektrochemischen Messungen in STW

Table 3. Corrosion parameters of carbon steel in hard tap water (HTW)

Tabelle 3. Korrosionsparametern des Kohlenstoffstahls in hartem Leitungswasser (HTW)

\begin{tabular}{llllllll}
\hline Inhibitor & $\begin{array}{l}\text { Conc. } \\
\mathbf{g l}^{-\mathbf{1}}\end{array}$ & $\begin{array}{l}\mathbf{E}_{\text {corr }} \\
\mathbf{m V}\end{array}$ & $\begin{array}{l}\mathbf{V}_{\text {corr }} \\
\mathbf{m m} \mathbf{y}^{-\mathbf{1}}\end{array}$ & $\begin{array}{l}\mathbf{j}_{\text {corr }} \\
\mu \mathbf{A c m}^{-2}\end{array}$ & $\begin{array}{l}\mathbf{R}_{\mathbf{p}} \\
\mathbf{k O h m s}\end{array}$ & $\mathbf{p H}$ & $\begin{array}{l}\mathbf{Z} \text { (efficiency) } \\
\%\end{array}$ \\
\hline- & 0 & -665 & 0.095 & 8.149 & 2.29 & 7.58 & 0 \\
Zn-gluconate & 0.1 & -616 & 0.05 & 4.275 & 6.927 & 7.42 & 47.37 \\
Zn-gluconate & 0.5 & -476 & 0.00675 & 0.5768 & 18.79 & 7.16 & 92.9 \\
Zn-gluconate & 1 & -427 & 0.003156 & 0.2698 & 40.12 & 7.095 & 96.68 \\
Zn-gluconate & 2 & -353 & 0.009471 & 0.81 & 47.97 & 7.075 & 90.03 \\
Zn-gluconate & 3 & -404 & 0.01448 & 1.238 & 39.2 & 6.927 & 84.76 \\
\hline
\end{tabular}

\subsection{The effect of ZG on corrosion inhibition in hard tap water (HTW)}

The effect of ZG concentration on protective properties of carbon steel in hard water was evaluated using 5 different $Z G$ concentrations $\left(0.1,0.5,1,2\right.$ and $\left.3 \mathrm{gl}^{-1}\right)$. Tafel polarization curves for above mentioned concentrations are presented in Figure 3 and compared to unprotected steel.

The values of corrosion parameters evaluated from electrochemical studies $\left(E_{\text {corr }}, v_{\text {corr }} j_{\text {corr }}, R_{\mathrm{P}}, Z\right)$ as well as $\mathrm{pH}$ values of investigated media are given in Tab. 3. Similar to previous research in STW, all employed ZG concentrations have tendency to shift $E_{\text {corr }}$ value in positive direction when compared to uninhibited curve and significantly reduce corrosion rate of carbon steel in HTW. Corrosion rate reaches its minimum at $1 \mathrm{gl}^{-1} \mathrm{ZG}$ whereas higher applied inhibitor concentrations slightly increase corrosion rate. The increase of applied inhibitor concentration increases the $R_{\mathrm{P}}$ value, with the exception of $3 \mathrm{gl}^{-1} \mathrm{ZG}$ which exhibited minor decrease of $R_{\mathrm{P}}$ value. Near neutral $\mathrm{pH}$ value and high protective cation content make this water type less corrosive $\left(0.095 \mathrm{mmy}^{-1}\right)$ when compared to STW, Tab. 1 . The lowest applied inhibitor concentration $\left(0.1 \mathrm{gl}^{-1} \quad \mathrm{ZG}\right)$ considerably reduces corrosion rate $(47.37 \%)$. Corrosion rate reduction is not pronounced as it is in STW. The increase of applied inhibitor concentration $\left(0.5 \mathrm{gl}^{-1} \mathrm{ZG}\right)$ further reduces corrosion rate $(92.9 \%)$. The maximal efficiency is achieved at $1 \mathrm{gl}^{-1} \mathrm{ZG}$ (96.68\%, 0.0032 $\mathrm{mmy}^{-1}$ ) and further increase of inhibitor concentration decreases the inhibitor efficiency. Generally it can be drawn that relative corrosion rate reduction (regarding to uninhibited medium) is more pronounced in STW but accomplished corrosion rates in absolute terms are lower in HTW. Surfaces of the carbon steel specimens after electrochemical research in HTW with $\left(1 \mathrm{gl}^{-1}\right.$ ZG) and without inhibitor addition are presented in Figure 4. Corrosion product formation is visible on steel carbon specimen from uninhibited medium, whereas a protected specimen is homogenous and mainly corrosion product free. Similar to experiments in STW, Tafel curves have a tendency to move toward positive potential values with the increase of inhibitor concentration, Figure 3. Therefore it can be concluded that ZG acts predominately as anodic inhibitor in this water type.

\subsection{The effect of ZG on corrosion inhibition in $3.5 \% \mathrm{NaCl}$ solution}

The effect of ZG concentration on protective properties of carbon steel in $3.5 \% \mathrm{NaCl}$ solution was evaluated using 5 different $\mathrm{ZG}$ concentrations $\left(0.1,0.5,1,2\right.$ and $\left.3 \mathrm{gl}^{-1}\right)$. Tafel polarization curves for the above mentioned concentrations are presented in Figure 5 and compared to unprotected steel. The values of corrosion parameters evaluated from electrochemical studies $\left(E_{\text {corr }}, v_{\text {corr }} j_{\text {corr }}\right.$ $R_{\mathrm{P}}, Z$ ) as well as $\mathrm{pH}$ values of investigated media are given in Tab. 4. Similar to previous researches in tap waters all employed ZG concentrations have tendency to shift the $E_{\text {corr }}$ value in positive direction when compared to uninhibited curve and to reduce the corrosion rate of carbon steel in $3.5 \% \mathrm{NaCl}$ solution significantly. The optimal efficiency is achieved at $1 \mathrm{gl}^{-1} \mathrm{ZG}(92.36 \%$, 


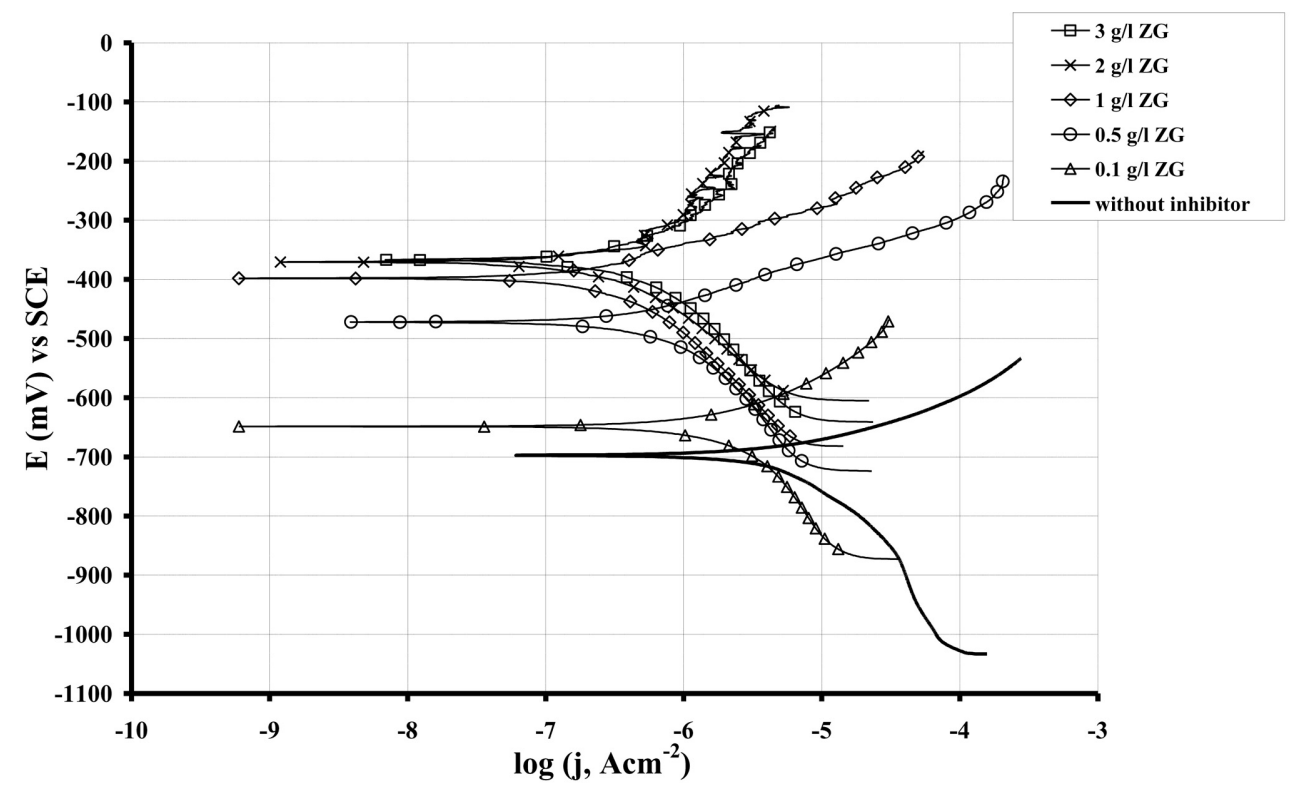

Figure 3. Tafel polarization curves of carbon steel in HTW

Bild 3. Tafel Polarisationskurven von Kohlenstoffstahl in HTW

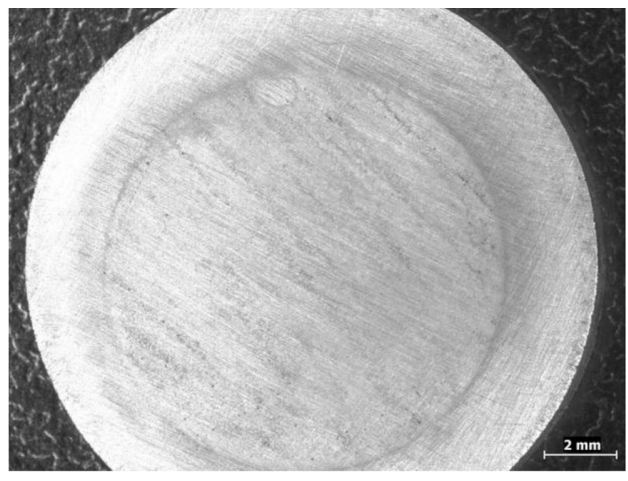

Without inhibitor

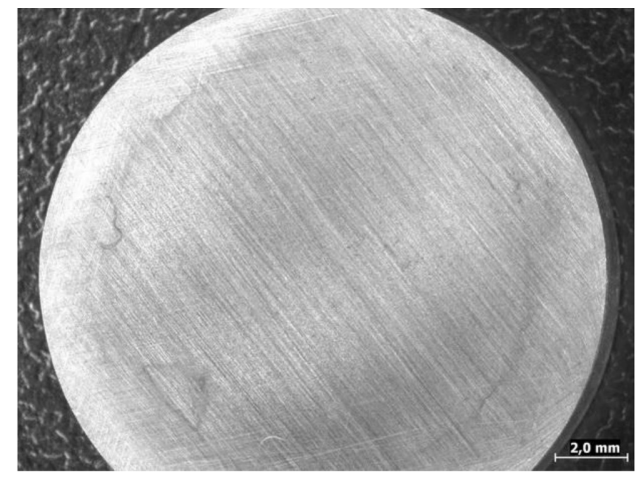

$1 \mathrm{gl}^{-1} \mathrm{ZG}$

Figure 4. Surface of the carbon steel specimens after electrochemical measurements in HTW

Bild 4. Oberfläche der Kohlenstoffstahlproben nach den elektrochemischen Messungen in HTW

Table 4. Corrosion parameters of carbon steel in $3.5 \% \mathrm{NaCl}$ solution

Tabelle 4. Korrosionsparameter des Kohlenstoffstahls in einer 3.5\% Natriumchloride Lösung

\begin{tabular}{llllllll}
\hline Inhibitor & $\begin{array}{l}\text { Conc. } \\
\mathbf{g l}^{-\mathbf{1}}\end{array}$ & $\begin{array}{l}\mathbf{E}_{\text {corr }} \\
\mathbf{m V}\end{array}$ & $\begin{array}{l}\mathbf{v}_{\text {corr }} \\
\mathbf{m m} \mathbf{y}^{-\mathbf{1}}\end{array}$ & $\begin{array}{l}\mathbf{j}_{\text {corr }} \\
\mu \mathbf{A c m}^{-2}\end{array}$ & $\begin{array}{l}\mathbf{R}_{\mathbf{p}} \\
\mathbf{k O h m s}\end{array}$ & $\mathbf{p H}$ & $\begin{array}{l}\mathbf{Z} \text { (efficiency) } \\
\%\end{array}$ \\
\hline- & 0 & -650 & 0.193 & 16.5 & 1.712 & 7.253 & 0 \\
Zn-gluconate & 0.1 & -618 & 0.09952 & 8.507 & 1.972 & 7.231 & 48.4 \\
Zn-gluconate & 0.5 & -540 & 0.01972 & 1.687 & 8.234 & 7.26 & 89.78 \\
Zn-gluconate & 1 & -587 & 0.01474 & 1.26 & 6.534 & 7.31 & 92.36 \\
Zn-gluconate & 2 & -516 & 0.01838 & 1.571 & 7.089 & 7.365 & 90.48 \\
Zn-gluconate & 3 & -509 & 0.01255 & 1.073 & 6.45 & 7.223 & 93.5 \\
\hline
\end{tabular}

$0.01474 \mathrm{mmy}^{-1}$ ) as further increase of the inhibitor concentration has no significant effect on the corrosion rate. The lowest applied inhibitor concentration $\left(0.1 \mathrm{gl}^{-1} \mathrm{ZG}\right)$ had minor effect on polarization resistance $\left(R_{\mathrm{P}}\right)$. Other applied ZG concentrations considerably increase $R_{\mathrm{P}}$ value (relative to uninhibited value), whereat those $R_{\mathrm{P}}$ values remain approximately constant. The ZG application in this concentration range has no significant effect on $\mathrm{pH}$ value, thus this type of medium is well buffered as opposed to tap waters. On the other hand, high chloride content is the main reason for high corrosiveness $\left(0.193 \mathrm{mmy}^{-1}\right)$ of this medium. 


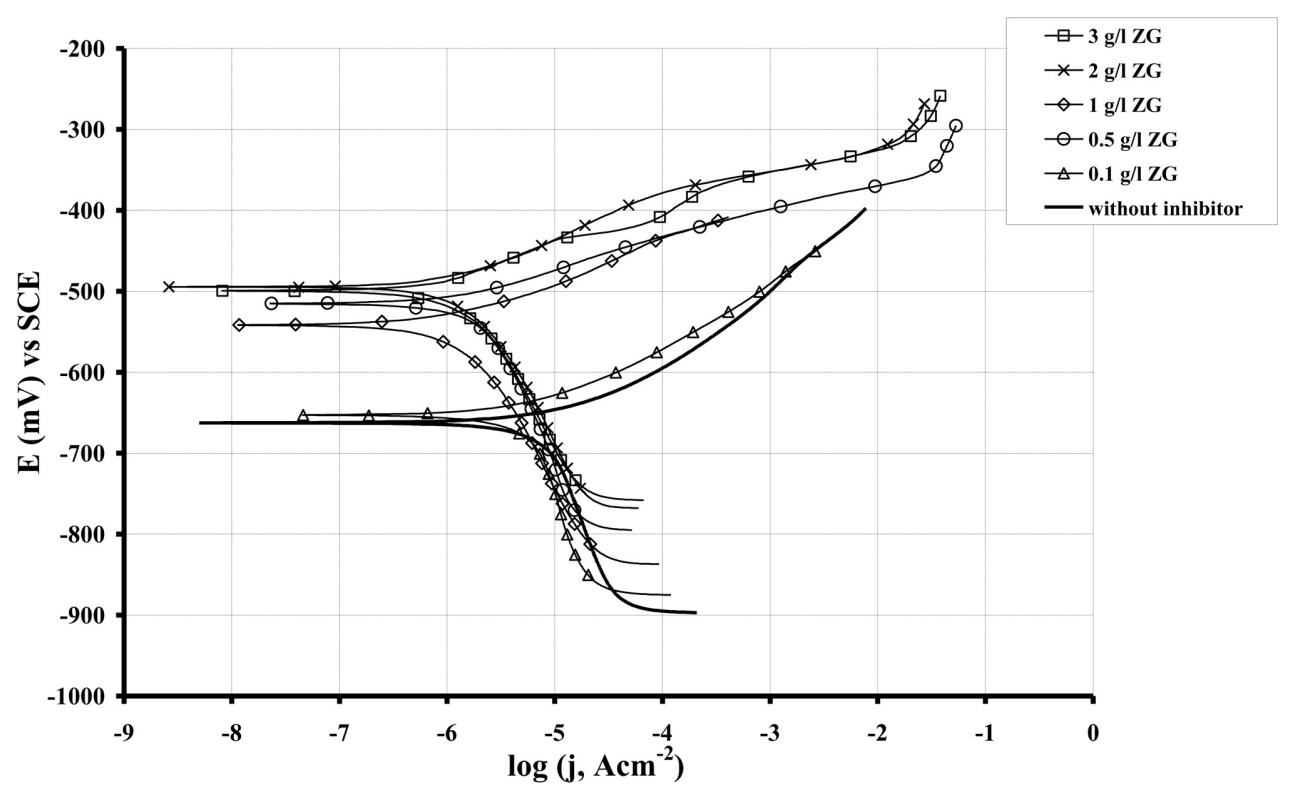

Figure 5. Tafel polarization curves of carbon steel in $3.5 \% \mathrm{NaCl}$ solution

Bild 5. Tafel Polarisationskurven von Kohlenstoffstahl in einer 3.5\% Natriumchloride Lösung

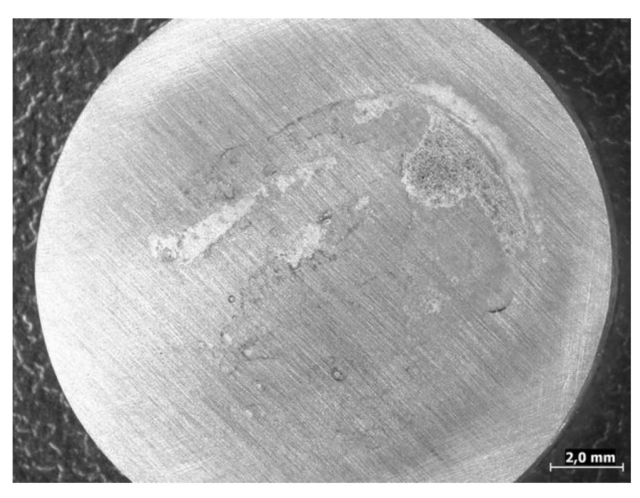

Without inhibitor

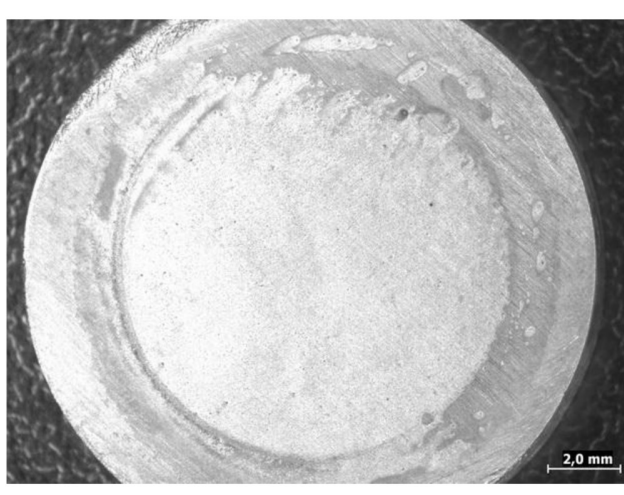

$1 \mathrm{~g} / \mathrm{ZG}$

Figure 6. Surface of the carbon steel specimens after electrochemical measurements in $3.5 \% \mathrm{NaCl}$ solution

Bild 6. Oberfläche der Kohlenstoffstahlproben nach den elektrochemischen Messungen in einer $3.5 \%$ Natriumchloride Lösung

The lowest applied inhibitor concentration $\left(0.1 \mathrm{gl}^{-1} \mathrm{ZG}\right)$ moderately reduces the corrosion rate $(48.4 \%)$. Corrosion rate reduction is not as pronounced as in experiments on tap waters. The increase of applied inhibitor concentration $\left(0.5 \mathrm{gl}^{-1} \mathrm{ZG}\right)$ considerably reduces the corrosion rate $(89.78 \%)$. Concentration of $1 \mathrm{gl}^{-1}$ ZG reaches $92.36 \%$ efficiency $\left(0.01474 \mathrm{mmy}^{-1}\right)$ and corrosion rate is not influenced significantly by a further increase of ZG concentration. Surfaces of the carbon steel specimens after electrochemical research in $3.5 \% \mathrm{NaCl}$ solution with $\left(1 \mathrm{gl}^{-1} \mathrm{ZG}\right)$ and without inhibitor addition are presented in Figure 6. Colored corrosion product formation is visible on steel carbon specimen from uninhibited medium, whereas protected specimen is more homogenous and contains less corrosion products. Similar to experiments in tap waters, Tafel curves have a tendency to move toward positive potential values with the increase of inhibitor concentration, Figure 5. However, this tendency is less expressed for the lowest applied ZG concentration. Therefore it can be concluded that ZG acts predominately as an anodic inhibitor in this water type. However, ZG also shows, to some extent, properties of mixed type inhibitor. In this particular case the effect of zinc cations (the effect on the cathodic reaction) is more prominent and is most obvious at $0.1 \mathrm{gl}^{-1} \mathrm{ZG}$ (similar to experiments accomplished in STW).

\subsection{The effect of ZG on corrosion inhibition in sea water (SW)}

The effect of ZG concentration on protective properties of carbon steel in sea water was evaluated using 5 different ZG concentrations $\left(0.1,0.5,1,2\right.$ and $\left.3 \mathrm{gl}^{-1}\right)$. Tafel polarization curves for the above mentioned concentrations are presented in Figure 7 and compared to unprotected steel. The values of corrosion param- 


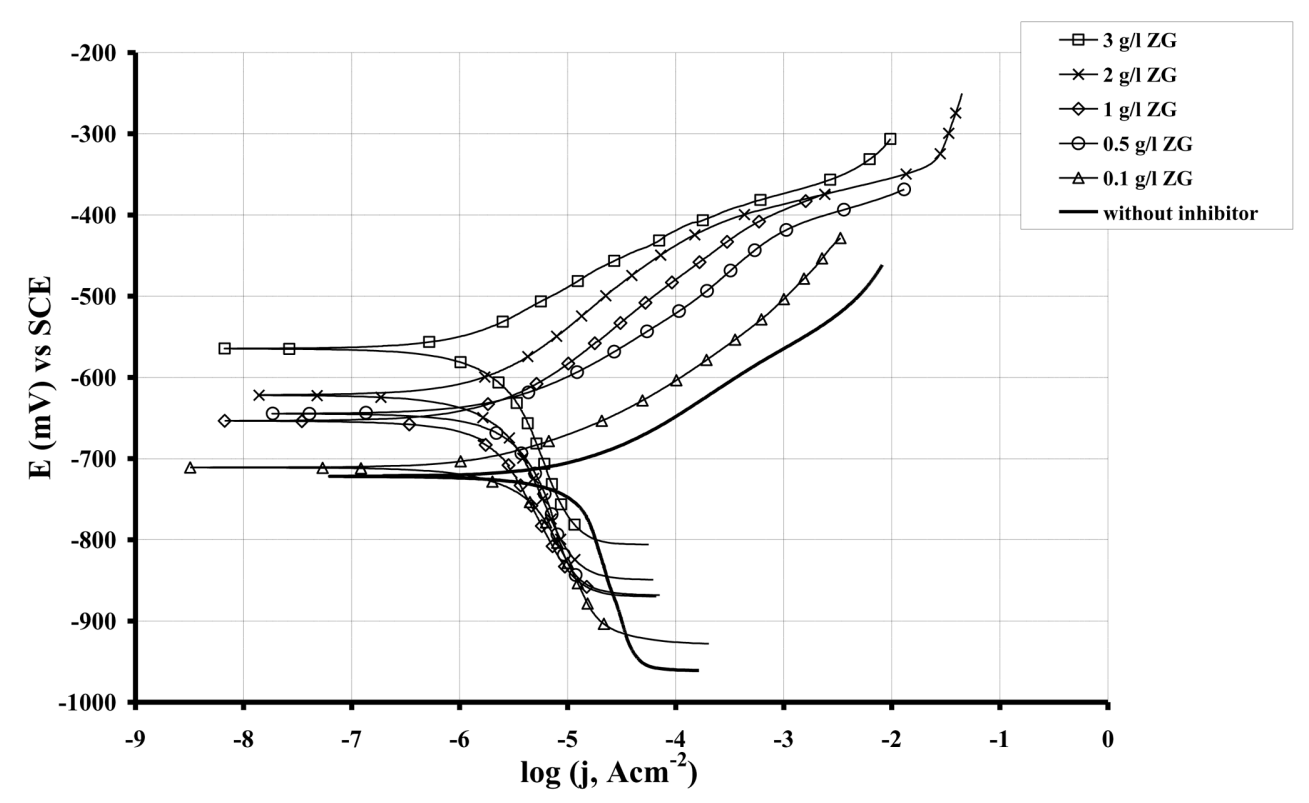

Figure 7. Tafel polarization curves of carbon steel in SW

Bild 7. Tafel Polarisationskurven von Kohlenstoffstahl in SW

eters evaluated from electrochemical studies $\left(E_{\text {corr, }}, v_{\text {corr }}, j_{\text {corr }}, R_{\mathrm{P}}, Z\right)$ as well as $\mathrm{pH}$ values of investigated media are given in Tab. 5 . Similar to the researches in STW, HTW and 3.5\% NaCl solution all employed ZG concentrations have a tendency to shift the $E_{\text {corr }}$ value in positive direction when compared to the uninhibited curve and significantly reduce corrosion rates of carbon steel in sea water. With the increase of applied ZG concentration $R_{\mathrm{P}}$ values are increasing too, and $\mathrm{pH}$ values are decreasing towards neutral $\mathrm{pH}$. High chloride content makes sea water very corrosive $\left(0.188 \mathrm{mmy}^{-1}\right)$. The lowest applied inhibitor concentration $\left(0.1 \mathrm{gl}^{-1} \mathrm{ZG}\right)$ significantly reduces corrosion rate $(73.63 \%)$ as opposed to the previous experiment with $3.5 \% \mathrm{NaCl}$. The increase of applied inhibitor concentration $\left(0.5 \mathrm{gl}^{-1} \mathrm{ZG}\right)$ doesn't effect corrosion rate $(73.2 \%)$ and concentration of $2 \mathrm{gl}^{-1} \mathrm{ZG}$ reaches efficiency of $88.22 \%\left(0.02214 \mathrm{mmy}^{-1}\right)$ which is not changing significantly by a further concentration increase. Surfaces of the carbon steel specimens after electrochemical research in sea water with $\left(1 \mathrm{gl}^{-1} \mathrm{ZG}\right)$ and without inhibitor addition are presented in Figure 8. In uninhibited medium bulk corrosion product is visible on whole exposed surface of carbon specimen, whereas protected specimen is more homogenous and contains less corrosion product. Similar to experiments performed in $3.5 \% \mathrm{NaCl}$ solution, Tafel curves have a tendency to move toward positive potential values with the increase of an inhibitor concentration, Figure 7. This tendency is less expressed at the lowest ZG concentration. Therefore it can be concluded that ZG acts predominately as an anodic inhibitor in sea water, although the effect of zinc ion on overall inhibitor efficiency is also expressed. In Figure 9 the scanning electron micrograph of the surfaces of unprotected and protected carbon steel specimens in sea water, and results of EDX analysis after electrochemical measurements are shown. The difference between samples is evident, unprotected sample exhibits distinctively non-homogenous surface with cluster of corrosion products. For same sample EDX anal- ysis confirmed the presence of characteristic corrosion indicators $(\mathrm{O}, \mathrm{S}, \mathrm{Cl})$. The protected sample had a surface of satisfactory homogeneity, without considerable corrosion formation. EDX analysis confirmed presence of $\mathrm{Zn}^{2+}$ ions which are presumably incorporated in the protective layer of carbon steel specimen.

\subsection{The effect of ZG on corrosion inhibition in demineralized water (DW)}

The effect of ZG concentration on protective properties of carbon steel in demineralized water was evaluated using 2 different $Z G$ concentrations $\left(0.5\right.$ and $\left.1 \mathrm{gl}^{-1}\right)$. Tafel polarization curves for the above mentioned concentrations are presented in Figure 10 and compared to unprotected steel. The values of corrosion parameters evaluated from electrochemical studies ( $E_{\text {corr }}, v_{\text {corr }} j_{\text {corr }}, R_{\mathrm{P}}, Z$ ) as well as $\mathrm{pH}$ values of investigated media are given in Tab. 6. As expected, corrosion rate in uninhibited DW was the lowest among investigated water types. All employed ZG concentrations have a tendency to shift $E_{\text {corr }}$ value in positive direction when compared to uninhibited curve and significantly reduce corrosion rate of carbon steel in DW. Inhibitor concentration of $0.5 \mathrm{gl}^{-1} \mathrm{ZG}$ considerably reduces corrosion rate $(88.93 \%)$. The increase of applied inhibitor concentration $\left(1 \mathrm{gl}^{-1} \mathrm{ZG}\right)$ further reduces corrosion rate (96.62\%). Surfaces of the carbon steel specimens after electrochemical research in DW with $0.5 \mathrm{gl}^{-1} \mathrm{ZG}$ and without inhibitor addition are presented in Figure 11. Corrosion product formation is slightly visible at the edges (contact surface) on the steel carbon specimen from the uninhibited medium, whereas the protected specimen is homogenous and corrosion product free. Similar to experiments in tap waters, Tafel curves have a tendency to move towards a positive potential values with the increase of inhibitor concentration, Figure 10. Therefore it can be concluded that ZG acts predominately as an anodic inhibitor in this water type. 


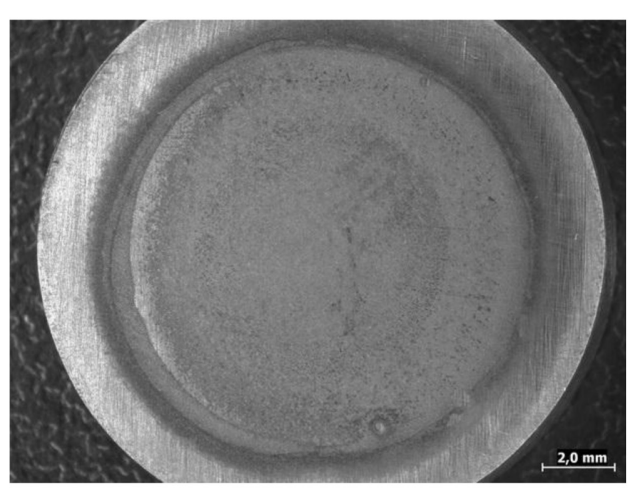

Without inhibitor

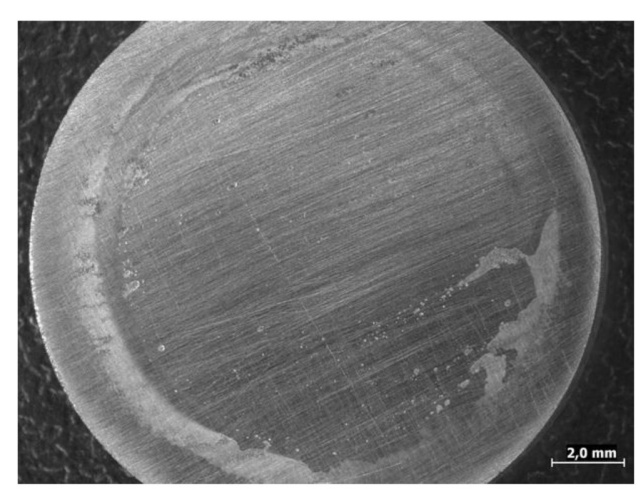

$1 \mathrm{gl}^{-1} \mathrm{ZG}$

Figure 8. Surface of the carbon steel specimens after electrochemical measurements in SW

Bild 8. Oberfläche der Kohlenstoffstahlproben nach den elektrochemischen Messungen in SW

Table 5. Corrosion parameters of carbon steel in sea water (SW)

Tabelle 5. Korrosionsparameter des Kohlenstoffstahls in Meerwasser (SW)

\begin{tabular}{|c|c|c|c|c|c|c|c|}
\hline Inhibitor & $\begin{array}{l}\text { Conc. } \\
\mathrm{gl}^{-1}\end{array}$ & $\begin{array}{l}\mathrm{E}_{\text {corr }} \\
\mathrm{mV}\end{array}$ & $\begin{array}{l}\mathbf{v}_{\text {corr }} \\
\mathbf{m m y}^{-1}\end{array}$ & $\begin{array}{l}\mathbf{j}_{\text {corr }} \\
\mu \mathrm{Acm}^{-2}\end{array}$ & $\begin{array}{l}R_{\mathrm{p}} \\
\text { kOhms }\end{array}$ & $\mathrm{pH}$ & $\begin{array}{l}Z \text { (efficiency) } \\
\%\end{array}$ \\
\hline - & 0 & -707 & 0.188 & 16.07 & 1.67 & 8.404 & 0 \\
\hline Zn-gluconate & 0.1 & -671 & 0.04958 & 4.238 & 1.88 & 8.294 & 73.63 \\
\hline Zn-gluconate & 0.5 & -619 & 0.05039 & 4.307 & 3.8 & 7.977 & 73.2 \\
\hline Zn-gluconate & 1 & -614 & 0.02889 & 2.469 & 5.673 & 7.73 & 84.63 \\
\hline Zn-gluconate & 2 & -590 & 0.02214 & 1.892 & 5.66 & 7.532 & 88.22 \\
\hline Zn-gluconate & 3 & -550 & 0.01933 & 1.652 & 7.48 & 7.36 & 89.72 \\
\hline
\end{tabular}

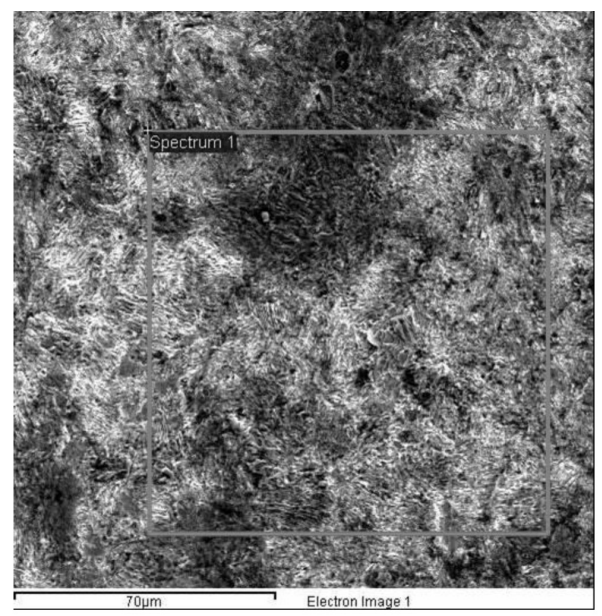

Without inhibitor

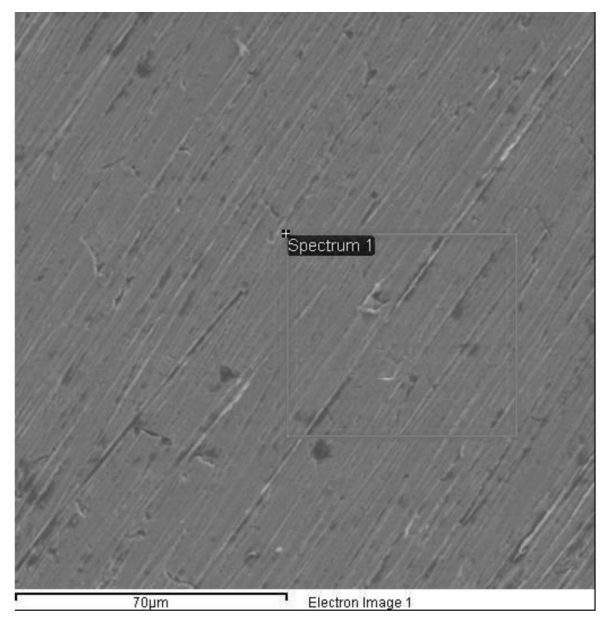

$1 \mathrm{gl}^{-1} \mathrm{ZG}$

\begin{tabular}{cccc}
\hline Element & Weight (\%) & Element & Weight (\%) \\
\hline $\mathrm{Mn}$ & 0.89 & $\mathrm{Mn}$ & 1.19 \\
$\mathrm{O}$ & 6.78 & $\mathrm{O}$ & 13.4 \\
$\mathrm{~S}$ & 0.01 & $\mathrm{~S}$ & 0.19 \\
$\mathrm{Cl}$ & 0.5 & $\mathrm{Zn}$ & 1.15 \\
\hline
\end{tabular}

Figure 9. Scanning electron micrograph of the surfaces of unprotected and protected carbon steel specimen in SW and the results of EDX analysis

Bild 9. Rasterelektronenmikroskopische Aufnahmen der Oberflächen von ungeschützten und geschützten Proben von Kohlenstoffstahl in SW und die Ergebnisse der EDX-Analyse. 


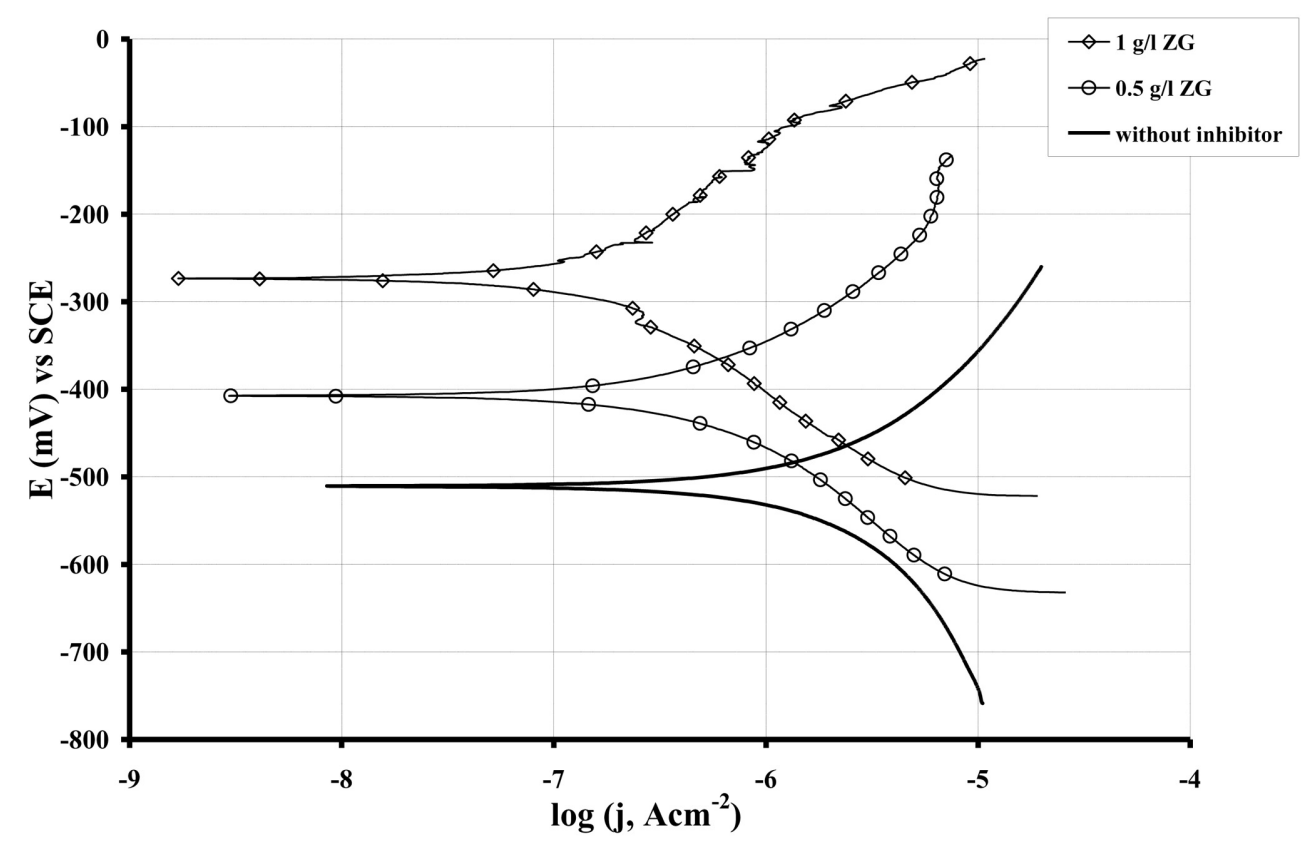

Figure 10. Tafel polarization curves of carbon steel in DW

Bild 10. Tafel Polarisationskurven von Kohlenstoffstahl in DW

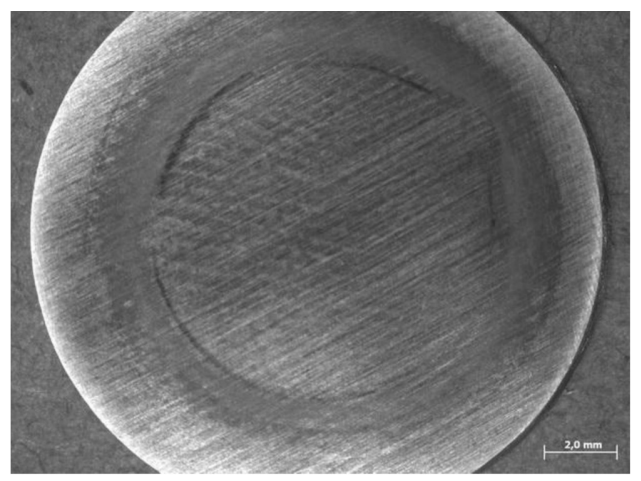

Without inhibitor

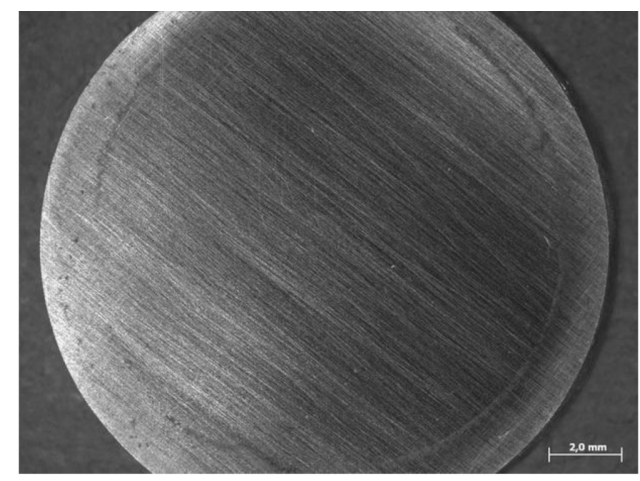

$0.5 \mathrm{gl}^{-1} \mathrm{ZG}$

Figure 11. Surface of the carbon steel specimens after electrochemical measurements in DW

Bild 11. Oberfläche der Kohlenstoffstahlproben nach den elektrochemischen Messungen in DW

\subsection{The effect of ZG on corrosion inhibition in biologically inert sea water (ISW)}

The effect of ZG concentration on protective properties of carbon steel in biologically inert sea water was evaluated using 2 different ZG concentrations ( 1 and $\left.2 \mathrm{gl}^{-1}\right)$. Tafel polarization curves for the above mentioned concentrations are presented in Figure 12 and compared to unprotected steel. The values of corrosion parameters evaluated from electrochemical studies ( $E_{\text {corr }}, v_{\text {corr }}, j_{\text {corr }}$, $R_{\mathrm{P}}, Z$ ) as well as $\mathrm{pH}$ values of investigated media are given in $\mathrm{Tab}$. 7. Inert sea water has higher $\mathrm{pH}$ value than ordinary sea water, which is the result of $\mathrm{CO}_{2}$ evaporation and thermal breakdown of organic acids originated from microbial metabolism, Tabs. 5 and 7. Since corrosion rate in ISW is considerably lower than in SW, those circumstances, along with $\mathrm{O}_{2}$ elimination dur- ing heating and boiling of the sea water could be crucial for corrosion rate decrease. In order to clarify the role of organic acids on corrosion rate, ultrafiltered sea water could be employed in future research. All employed ZG concentrations have a tendency to shift $E_{\text {corr }}$ value in the positive direction when compared to uninhibited curve without considerable differences between employed concentrations and significantly reduce corrosion rate of carbon steel in ISW. An inhibitor concentration of $1 \mathrm{gl}^{-1} \mathrm{ZG}$ considerably reduces corrosion rate $(80.21 \%)$. The increase of applied inhibitor concentration $\left(2 \mathrm{gl}^{-1} \mathrm{ZG}\right)$ further reduces corrosion rate $(89.14 \%)$. Those values are highly similar to results obtained in sea water. Surfaces of the carbon steel specimens after electrochemical research in ISW with $2 \mathrm{gl}^{-1} \mathrm{ZG}$ and without inhibitor addition are presented in Figure 13. In uninhibited 
Table 6. Corrosion parameters of carbon steel in demineralized water (DW)

Tabelle 6. Korrosionsparameter des Kohlenstoffstahls in demineralisiertem Wasser (DW)

\begin{tabular}{llllllll}
\hline Inhibitor & $\begin{array}{l}\text { Conc. } \\
\mathbf{g l}^{-\mathbf{1}}\end{array}$ & $\begin{array}{l}\mathbf{E}_{\text {corr }} \\
\mathbf{m V}\end{array}$ & $\begin{array}{l}\mathbf{V}_{\text {corr }} \\
\mathbf{m m y ^ { - 1 }}\end{array}$ & $\begin{array}{l}\mathbf{j}_{\text {corr }} \\
\mu \mathbf{A c m}^{-2}\end{array}$ & $\begin{array}{l}\mathbf{R}_{\mathbf{p}} \\
\mathbf{k O h m s}\end{array}$ & $\mathbf{p H}$ & $\begin{array}{l}\mathbf{Z} \text { (efficiency) } \\
\%\end{array}$ \\
\hline- & 0 & -507 & 0.06427 & 5.497 & 25.64 & 5.9 & 0 \\
Zn-gluconate & 0.5 & -374 & 0.007115 & 0.6086 & 25.41 & 6.47 & 88.93 \\
Zn-gluconate & 1 & -263 & 0.002173 & 0.1859 & 63.23 & 6.99 & 96.62 \\
\hline
\end{tabular}

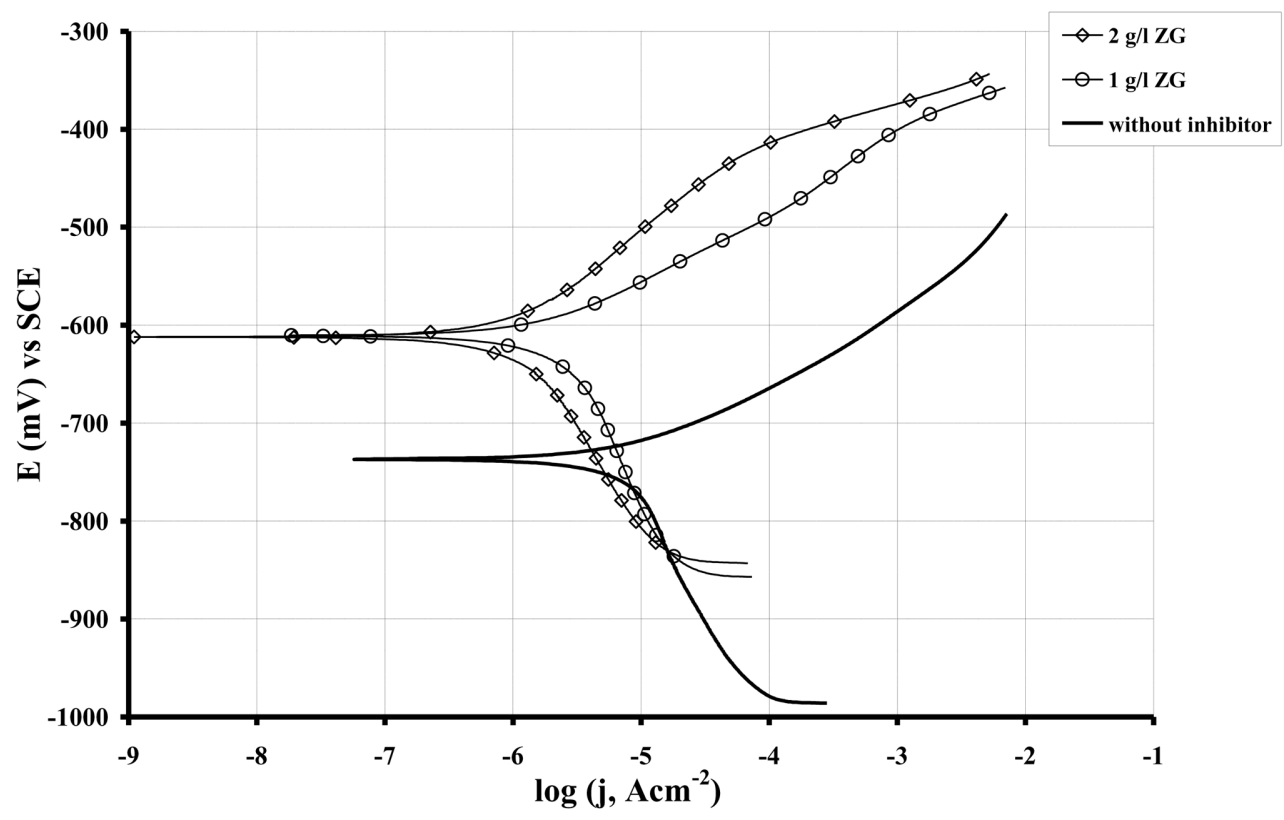

Figure 12. Tafel polarization curves of carbon steel in ISW

Bild 12. Tafel Polarisationskurven von Kohlenstoffstahl in ISW

Table 7. Corrosion parameters of carbon steel in inert sea water (ISW)

Tabelle 7. Korrosionsparameter des Kohlenstoffstahls in inertem Meerwasser (ISW)

\begin{tabular}{llllllll}
\hline Inhibitor & $\begin{array}{l}\text { Conc. } \\
\mathbf{g l}^{\mathbf{1}}\end{array}$ & $\begin{array}{l}\mathbf{E}_{\text {corr }} \\
\mathbf{m V}\end{array}$ & $\begin{array}{l}\mathbf{V}_{\text {corr }} \\
\mathbf{m m y ^ { - 1 }}\end{array}$ & $\begin{array}{l}\mathbf{j}_{\text {corr }} \\
\mu \mathbf{A c m}^{-2}\end{array}$ & $\begin{array}{l}\mathbf{R}_{\mathbf{p}} \\
\mathbf{k O h m s}\end{array}$ & $\mathbf{p H}$ & $\begin{array}{l}\mathbf{Z} \text { (efficiency) } \\
\%\end{array}$ \\
\hline- & 0 & -730 & 0.1415 & 12.1 & 1.719 & 9.015 & 0 \\
Zn-gluconate & 1 & -607 & 0.028 & 2.404 & 3.738 & 7.96 & 80.21 \\
Zn-gluconate & 2 & -598 & 0.01537 & 1.314 & 5.505 & 7.69 & 89.14 \\
\hline
\end{tabular}

medium corrosion product is visible on whole exposed surface of carbon specimen, whereas on protected specimen corrosion is more localized and restricted to certain areas of steel specimen. Tafel curves have a tendency to move towards the positive potential values but with the increase of inhibitor concentration this tendency is diminished. Figure 12.

\section{Conclusions}

In conclusion it can be stated that ZG is an effective corrosion inhibitor for carbon steel in all investigated water types. Nevertheless, the mechanism and the extent of ZG protective properties are highly dependent on water type. The main parameters that influence ZG efficiency are chloride content, $\mathrm{pH}$ value, water hardness and content of protective cathions already present in water (mainly $\mathrm{Ca}^{2+}$ and $\mathrm{Mg}^{2+}$ ). Chloride content has a prevailing effect on the mechanism of ZG inhibitive action. In all investigated water types ZG inhibition is predominately obtained by blocking the anodic reaction. Nevertheless, at the lowest applied ZG concentration $\left(0.1 \mathrm{gl}^{-1}\right)$, especially in high chloride environment it becomes evident that $\mathrm{ZG}$ inhibition effect is observable on cathodic sites too. The detrimental effect of chlorides on the anodic sites aggravates formation of gluconate protective film formation, which makes cathodic inhibition by $\mathrm{Zn}^{2+}$ ions more evident and results in an overall perception of $\mathrm{ZG}$ as a mixed inhibitor. EDX analysis confirmed the presence of $\mathrm{Zn}^{2+}$ ions (experiment with sea water) which are incorporated in the 


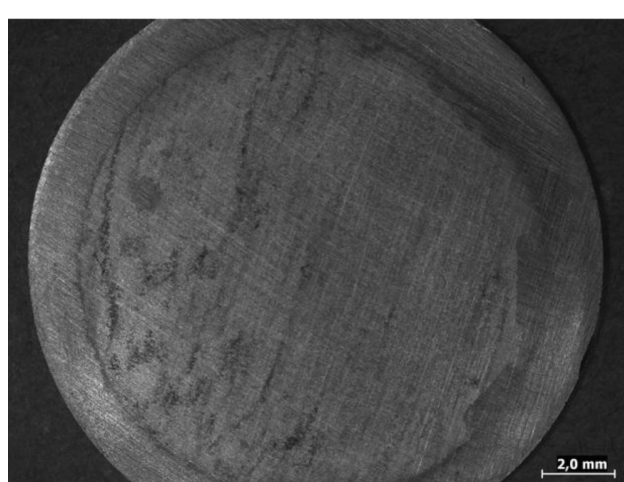

Without inhibitor

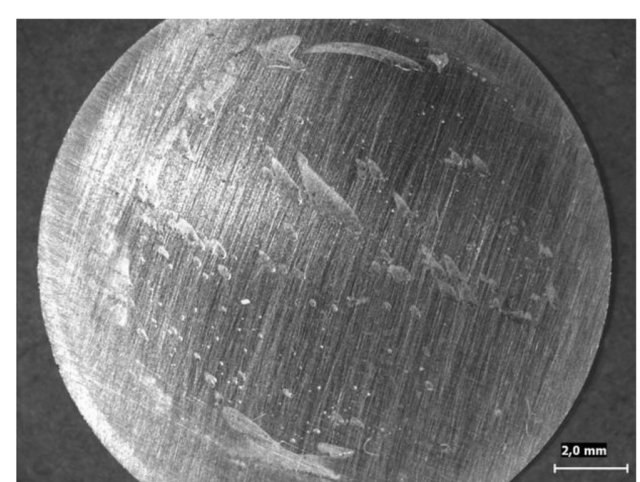

$2 \mathrm{gl}^{-1} \mathrm{ZG}$

Figure 13. Surface of the carbon steel specimens after electrochemical measurements in ISW

Bild 13. Oberfläche der Kohlenstoffstahlproben nach den elektrochemischen Messungen in ISW

protective layer of carbon steel specimen. Therefore, dual (ano$\mathrm{dic}$ (cathodic) action is reason for high applicability of ZG in variety of different environments. Since investigated water types are considerably different regarding corrosion properties, ZG concentrations required to obtain satisfactory inhibition ( $90 \%)$ are also different for specific water types. From the results of this work those optimal values can be estimated as follows: $0.5 \mathrm{gl}^{-1}$ ZG - DW, STW, HTW, i.e. waters with low chloride content, $1 \mathrm{gl}^{-1}-3.5 \% \mathrm{NaCl}, 2 \mathrm{gl}^{-1}-\mathrm{SW}$, ISW. Inhibition efficiencies at given ZG concentrations are: $88.93 \%$ (DW), 96.93\% (STW), 92.9\% (HTW), $92.36 \%(3.5 \% \mathrm{NaCl}$ ), $88.22 \%$ (SW), $89.14 \%$ (ISW). Local corrosion, particularly in the case of ISW could further be prevented by mixing zinc gluconate with other inhibitors, and this will be elaborated in future research.

\section{References}

[1] M. Saremi, N. Parsi Benehkohal, C. Dehghanian, H.R. Zebardast, Corrosion 2009, 65, 778.

[2] R. Touir, M. Cenoui, M. El Bakri, M. Ebn Touhami, Corros. Sci. 2008, 50, 1530.

[3] S. M. A. Shibli, V. A. Kumary, Anti-Corros. Method. M. 2004, 51, 277.

[4] D. van Loyen, G. Zocher, Werkst. Korros. 1990, 41, 613.

[5] P. R. Puckorius, S. D. Strauss, Power 1995, 139, 17.

[6] J. Telegdi, E. Kálmán, F. H. Kármán, Corros. Sci. 1992, 33, 1099.
[7] X. Liu, J. Han, C. Sun, Y. Rui, Q. Wang, Corros. Prot. 2012, 33, 296.

[8] D. Q. Zhang, X. Jin, B. Xie, H. Goun Joo, L. X. Gao, K. Y. Lee, Surf. Interface Anal. 2012, 44, 78.

[9] M. Mahdavian, R. Naderi, Corros. Sci. 2011, 53, 1194.

[10] O. Lahodny-Šarc, F. Kapor, Mater. Corros. 2002, 53, 264.

[11] O. Lahodny-Šarc, F. Kapor, R. Halle, Werkst. Korros. 2000, 51, 147.

[12] S. Rajendran, R. Maria Joany, B. V. Apparao, N. Palaniswamy, Trans. SAEST 2000, 35, 113.

[13] S. A. M. Refaey, Appl. Surf. Sci. 2000, 157, 199.

[14] O. Lahodny-Šarc, F. Kapor, Mater. Sci. Forum 1998, 289292, 1205.

[15] S. Rajendran, B. V. Apparao, N. Palaniswamy, Br. Corros. J. 1998, 33, 315.

[16] O. Lahodny-Šarc, presented at 8th Europ. Symp. Corr. Inhibitors, Ferrara, Italy, 1995, 421-433.

[17] S. H. Shim, D. P. Bakalik, D. A. Johnson, B. Yang, F. F. Lu, US Patent 5589106, 1996.

[18] O. Lahodny-Šarc, presented at 5th Europ. Symp. Corr. Inhibitors, Ferrara, Italy, 1980, 609-628.

[19] O. Lahodny-Šarc, RAD Yug. Acad. Sc. Q Arts 1982, 394/18, 1.

[20] O. Lahodny-Šarc, P. Orlovic-Leko, presented at Internat. Conf. UK Corrosion and Eurocorr 94, Bournemouth, UK, 1994, 120.

[21] V.M. Kadek, L.K. Lepin, presented at $3^{\text {rd }}$ Europ. Symp. Corr. Inhibitors, Ferrara, Italy, 1970, 643.

Received in final form: July $11^{\text {th }} 2012$

T 47 